\title{
Neonatal cardiovascular emergencies after hospital discharge
}

\author{
Nicola Pozzi, Anna Casani, Francesco Cocca, Concetta Coletta, Maria Gabriella De Luca, Gaetano Di Manso, \\ Lidia Grappone, Alessandro Scoppa, Luigi Orfeo
}

From XX National Congress of the Italian Society of Neonatology

Rome, Italy. 9-11 October 2014

Neonates with out-of-hospital cardiovascular emergencies get to Emergency Department or Neonatal Intensive Care Unit in a state of shock, which is a complex clinical syndrome characterized by an acute failure of the circulatory system with inadequate tissue and organ perfusion.

It has been demonstrated that early recognition and time-sensitive aggressive resuscitation of neonatal shock significantly reduce mortality and improve outcomes [1].

The update algorithm for goal-directed treatment of neonatal shock emphasizes early use of therapies directed to restore threshold heart rates, normalize blood pressure and capillary refill $\leq 2$ seconds and subsequent intensive hemodynamic support aimed to goals of central venous oxygen saturation $(\mathrm{ScvO} 2)>70 \%$ and cardiac index $(\mathrm{CI})>3.3 \mathrm{~L} / \mathrm{min} / \mathrm{m}^{2}[2]$.

Rapid attainment of a vascular access is pivotal for fluid resuscitation and inotrope therapy and an intraosseous needle must be early inserted especially in the case of cardiac arrest or decompensated shock [3].

Rapid crystalloid boluses of 10-20 ml/kg (over 5 10 minutes) up to $60 \mathrm{ml} / \mathrm{kg}$ in the first hour must be administered paying attention to signs of fluid overload because overaggressive therapy can be detrimental in case of cardiogenic shock. An echocardiographic analysis can help clinicians to assess the inferior vena cava diameter or collapsibility as an index of preload status [4] and to evaluate the ventricular size and contractility to identify a cardiogenic shock [5]. Prostaglandin infusion is recommended until a ductal-dependent lesion is ruled out by trained echocardiographists.

Empiric antibiotics should be administered within one hour if a sepsis is suspected [6].

* Correspondence: nicolapozzi71@gmail.com

Neonatal Intensive Care Unit, Maternal and Child Health Department, "G. Rummo" Hospital, via dell'Angelo 1, 82100 Benevento, Italy
Neonates with fluid refractory shock need to start and titrate a peripheral inotropic support and progressively to be added vasopressors according to the hemodynamic state.

Many methods are available for the hemodynamic monitoring after the first hour of stabilization of the neonate. A safer ultrasound-guided central venous access can easily be obtained [7] and ScrO2 be measured. The radial arterial pressure monitoring is recommended and the arterial waveform can be used to derive additional hemodynamic information. The monitoring of $\mathrm{CI}$ is feasible in neonates only by non-invasive methods such as doppler echocardiography or impedance cardiography [8].

Many aspects of the intensive hemodynamic support of neonatal shock resemble those of paediatric critical care medicine (PCCM) usually provided by anaesthesiologists.

We believe that neonatologists need a specific PCCM training before dealing with critically ill neonates and for this purpose our team has devised some courses (Figure 1) to meet these particular educational and procedural skill needs.

\section{Published: 9 October 2014}

\section{References}

1. Han YY, Carcillo JA, Dragotta MA, Bills DM, Watson RS, Westerman ME, Orr RA: Early reversal of pediatric-neonatal septic shock by community physicians is associated with improved outcome. Pediatrics 2003, 112:793-799.

2. Brierley J, Carcillo JA, Choong K, Cornell T, Decaen A, Deymann A, Doctor A, Davis A, Duff J, Dugas MA, Duncan A, Evans B, Feldman J, Felmet K, Fisher G, Frankel L, Jeffries H, Greenwald B, Gutierrez J, Hall M, Han YY, Hanson J, Hazelzet J, Hernan L, Kiff J, Kissoon N, Kon A, Irazuzta J, Lin J, Lorts A, Mariscalco M, Mehta R, Nadel S, Nguyen T, Nicholson C, Peters M, Okhuysen-Cawley R, Poulton T, Relves M, Rodriguez A, Rozenfeld R, Schnitzler E, Shanley T, Kache S, Skippen P, Torres A, von Dessauer B, Weingarten J, Yeh T, Zaritsky A, Stojadinovic B, Zimmerman J, Zuckerberg A: Clinical practice parameters for hemodynamic support of pediatric and 


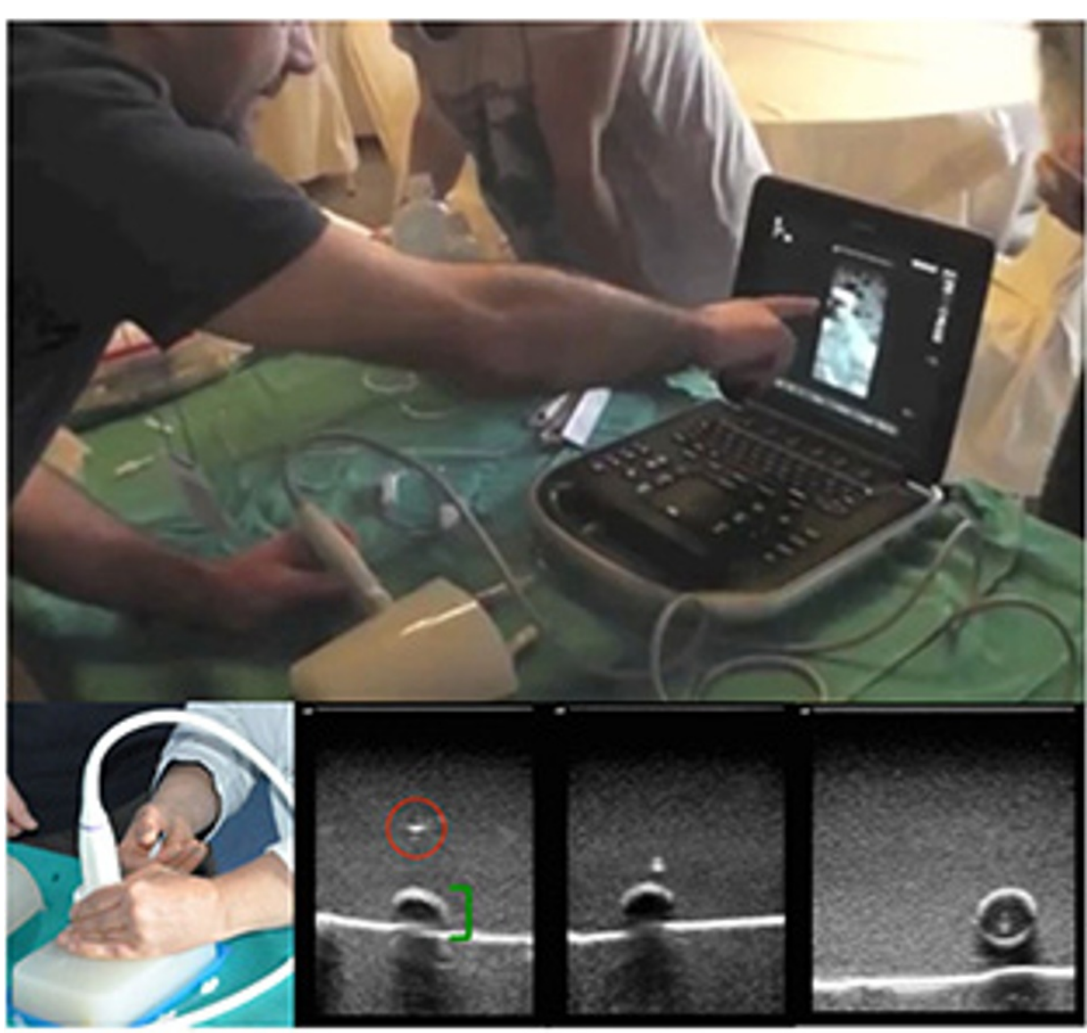

Figure 1 Simulation-based training of an ultrasound-guided central venous catheterization. The figure illustrates the ultrasound-guided vessel puncture technique by using phantoms. The trainee visualizes the simulated vessel in transverse scans (short axis) and advances the needle tip (red circle) towards the vessel (green square bracket) during the procedure.

neonatal septic shock: 2007 update from the American College of Critical Care Medicine. Crit Care Med 2009, 37(2):666-688.

3. Biarent D, Binghamb R, Eichc C, López-Herced J, Maconochiee I, RodríguezNúnezf A, Rajkag T, Zidemanh D: European resuscitation council guidelines for resuscitation 2010 section 6. Paediatric life support. Resuscitation 2010, 81:1364-1388.

4. Mertens L, Seri I, Marek J, Arlettaz R, Barker P, McNamara P, Moon-Grady AJ, Coon PD, Noori S, Simpson J, Lai WW, Writing Group of the American

Society of Echocardiography (ASE), European Association of Echocardiography (EAE), Association for European Pediatric Cardiologists (AEPC): Targeted neonatal echocardiography in the neonatal intensive care unit: practice guidelines and recommendations for training. European Journal of Echocardiography 2011, 12:715-736.

5. Perera P, Mailhot T, Riley D, Mandavia D: The RUSH exam: Rapid Ultrasound in SHock in the evaluation of the critically ill. Emerg Med Clin North Am 2010, 28(1):29-56

6. Dellinger RP, Levy MM, Rhodes A, Annane D, Gerlach H, Opal SM, Sevransky JE, Sprung CL, Douglas IS, Jaeschke R, Osborn TM, Nunnally ME, Townsend SR, Reinhart K, Kleinpell RM, Angus DC, Deutschman CS, Machado FR, Rubenfeld GD, Webb SA, Beale RJ, Vincent JL, Moreno R, Surviving Sepsis Campaign Guidelines Committee including the Pediatric Subgroup: Surviving sepsis campaign: international guidelines for management of severe sepsis and septic shock: 2012. Crit Care Med 2013, 41(2):580-637.

7. Troianos CA, Hartman GS, Glas KE, Skubas NJ, Eberhardt RT, Walker JD, Reeves ST, Councils on Intraoperative Echocardiography and Vascular Ultrasound of the American Society of Echocardiography: Guidelines for performing ultrasound guided vascular cannulation: recommendations of the American Society of Echocardiography and the Society of Cardiovascular Anesthesiologists. J Am Soc Echocardiogr 2011, 24(12):1291-318
8. Soleymani S, Borzage M, Noori S, Seri I: Neonatal hemodynamics: monitoring, data acquisition and analysis. Expert Rev Med Devices 2012, 9(5):501-11.

\section{doi:10.1186/1824-7288-40-S2-A30}

Cite this article as: Pozzi et al:: Neonatal cardiovascular emergencies after hospital discharge. Italian Journal of Pediatrics 2014 40(Suppl 2):A30.

\section{Submit your next manuscript to BioMed Central and take full advantage of:}

- Convenient online submission

- Thorough peer review

- No space constraints or color figure charges

- Immediate publication on acceptance

- Inclusion in PubMed, CAS, Scopus and Google Scholar

- Research which is freely available for redistribution
Ciomed Central 